\title{
Fake news and real news: What are their characteristics and how to identify them in a school and in COVID-19 pandemic context? A proposal for scientific literacy adapted to emergency remote education
}

\author{
Fake news e notícias reais: Quais são suas características e como identificá-las em um contexto \\ escolar e de pandemia COVID-19? Uma proposta de alfabetização científica adaptada ao ensino \\ remoto emergencial \\ Noticias falsas y noticias reales: ¿Cuáles son sus características y cómo identificarlas en una escuela \\ y en el contexto de la pandemia de COVID-19? Una propuesta de alfabetización científica adaptada \\ a la educación a distancia de emergencia
}

Received: 10/05/2021 | Reviewed: 10/10/2021 | Accept: 10/12/2021| Published: 10/14/2021

\author{
Renato Corrêia Lima \\ ORCID: https://orcid.org/0000-0001-9619-912X \\ Instituto Nacional de Pesquisas da Amazônia, Brazil \\ E-mail: renatocorreia.lima@hotmail.com \\ Adriana Oliveira Freitas \\ ORCID: https://orcid.org/0000-0002-6656-4410 \\ Universidade Federal do Maranhão, Brazil \\ E-mail: adriana.oliveira.freitas@outlook.com \\ Jacqueline da Silva Batista \\ ORCID: https://orcid.org/0000-0002-6649-6200 \\ Instituto Nacional de Pesquisas da Amazônia, Brazil \\ E-mail: jac@inpa.gov.br \\ Vinícius Rocha da Silva \\ ORCID: https://orcid.org/0000-0003-2113-502X \\ Universidade Estadual do Maranhão, Brazil \\ E-mail: viniciusbiologo10@ hotmail.com
}

\begin{abstract}
This case study aimed to apply, adapt and then evaluate a didactic approach to combat fake news, through scientific literacy in the context of emergency remote education (ERE) with a focus on COVID-19. For this, virtual workshops were held in 2020 with high school students from two public schools in the state of Maranhão, Brazil. All the ethical guidelines of Resolution CNS 510/2016 were followed. In the workshops, the students were exposed to the situationproblem of differentiating fake news from reliable news by identifying typical characteristics of either type of information. There were 18 characteristics for fake news and 18 characteristics for reliable news, of which $50 \%$ and $83.3 \%$ are unpublished, respectively. In addition, four fake news features and four reliable news features were observed by the students exclusively related to COVID-19. Thus, the adaptation to ERE that is proposed in the present study proved effective and could subsidize any work that aims to prepare students to better understand what is true and what is untrue in the world of the Internet, especially regards to in social media.
\end{abstract}

Keywords: High school; Basic education; Social networks.

\section{Resumo}

O presente estudo de caso objetivou aplicar, adaptar e avaliar uma abordagem didática de combate a fake news, por meio de alfabetização científica no âmbito do Ensino Remoto Emergencial (ERE) com foco na COVID-19. Para isso, oficinas virtuais foram realizadas no ano de 2020 com estudantes do Ensino Médio de duas escolas públicas do Estado do Maranhão. Todas as orientações éticas da Resolução CNS 510/2016 foram seguidas. Nessa oficina os estudantes foram expostos a situação problema de diferenciar fake news de notícias confiáveis identificando características típicas de ambos os tipos de informações. Foram percebidas 18 características de fake news e 18 características de notícias confiáveis, sendo que $50 \%$ e $83,3 \%$ das quais são inéditas, respectivamente. Além disso, quatro características de fake news e quatro características de notícias confiáveis exclusivamente relacionadas a COVID-19 foram observadas pelos estudantes. Dessa maneira, a adaptação ao ERE proposta no presente estudo mostrou-se eficaz 
e poderá subsidiar trabalhos que visem preparar estudantes a perceberem melhor o que é verdade e o que é mentira no mundo da internet, em especial nas mídias sociais.

Palavras-chave: Ensino médio; Educação básica; Redes sociais.

\section{Resumen}

Este caso de estudio tuvo como objetivo aplicar, adaptar y evaluar un enfoque didáctico para combatir las fake news, mediante de la alfabetización científica en el contexto de la Educación Remota en Emergencias (ERE) con enfoque en COVID-19. Para ello, en 2020 se realizaron talleres virtuales con estudiantes de secundaria de dos escuelas públicas del estado de Maranhão. Se siguieron todas las pautas éticas de la Resolución CNS 510/2016. En este taller se expuso a los alumnos la situación problemática de diferenciar noticias falsas de noticias confiables, identificando características típicas de ambos tipos de información. Se percibieron 18 características de noticias falsas y 18 características de noticias confiables, de las cuales el $50 \%$ y el 83,3\% son inéditas, respectivamente. Además, los estudiantes notaron cuatro características de noticias falsas y cuatro características de noticias confiables relacionadas exclusivamente con COVID-19. De esta forma, la adaptación al ERE propuesta en este estudio demostró ser efectiva y puede apoyar trabajos dirigidos a preparar a los estudiantes para comprender mejor qué es verdad y qué es mentira en el mundo de internet, especialmente en las redes sociales.

Palabras clave: Bachillerato; Educación básica; Redes sociales.

\section{Introduction}

Fake news is understood as reports that simulate the content of journalistic media, but has an organizational process that is distinct in its objective and the rigorousness of its revision (Lazer et al., 2018). Fake news has been part of human history since humans began living in groups (Burkhardt, 2017) and it has already been responsible for great injustices that have resulted in the deaths of a large number of people (Harari, 2018).

With the advent of social media, fake news has gained a great vehicle for its dissemination, since social media is an effective means of building and spreading knowledge, especially at times when there is a lot of uncertainty and a high demand for information on issues such as crises (Spence et al., 2016, Jang and Kim 2018) and concerns regarding health (Jang et al., 2017), as is the case of the pandemic of the new coronavirus (SARS-CoV-2 virus, which causes COVID-19) that was decreed in December 2019. In a study conducted in Italy, it was found that links containing fake news had a $23.1 \%$ share in relation to the total shares of all articles reviewed (Moscadelli et al., 2020) with a predominance in social networks.

The population does not ignore such a problem and it seeks to be informed about COVID-19 in order to obtain help and guidance in this difficult moment. A considerable proportion of people rely on news from any type of publication, spread, above all, on social networks, without proper verification of the authenticity of the information. As such, fake news of various contents, such as recipes for miraculous remedies, the discovery of the origin of the disease and prophecies, are all disseminated. Content like these impresses people, especially the most secular and who go through a confusing moment and, as a result, live in fear. Fake news is therefore aggravating the public health crisis and causing chaos and despair (Sousa Júnior et al., 2020).

If we take into account that the currently most used social network, WhatsApp, was only founded in 2009, we can say that the thunderous breadth with which fake news can reproduce on social networks is a relatively new phenomenon. This can often diminish the interest in the veracity of the news and the critical reading ability to identify what is false (FernándezGarcia, 2018). Awareness of the fight against fake news has never been so necessary as it is today, and the interest in developing it has been renewed with the growth of its negative effects on society. Given the relevance of the topic, Gravina and Munk (2019) proposed an approach aimed at literacy and scientific literacy in basic school education as a means of identifying and confronting fake news. Since new generations get their information on social networks and other internet resources, they must learn to decode and discriminate what they read (Kahne \& Bowyer, 2017).

Science can be interpreted as the knowledge that enables the expression of individuals through language and that, in scientific terms, literate people know how to read the language in which nature is written (Chassot, 2003). The terms "learning 
to read and write" and "literacy" are very close, but they have fundamental differences from each other. Learning to read and write is related to the skills and knowledge that constitute learning scientific reading and writing at the individual level, while literacy is linked to scientific reading and writing practices at the social level (Mamede \& Zimmermann 2005).

The pandemic of the new coronavirus has changed the routine and the protocols employed in the education due to the suspension of face-to-face classes at all levels of classes in most of Brazil and the rest of the world. These changes were sudden and forced teachers and students to adhere to emergency remote education (ERE) in order to meet the demands of education and avoid jeopardizing the school year in 2020 (Beneditto, 2020; Ludovico et al., 2020).

With this new model, teachers had the responsibility of developing effective activities for the promotion of learning situations that could be carried out remotely with students, outside the academic environment, which as a result created numerous challenges for teachers and students: the difficulties of access to information and communication technologies (ICTs), access to and quality of Internet service, mental health being affected by prolonged isolation and social distancing, family members affected by the disease, lack of resources and the existence of social vulnerability that hinders the implementation of practices that include all students (Beneditto, 2020; Ludovico et al., 2020).

A considerable proportion of teachers were not trained to work with ICTs in their initial training; and using the technologies does not mean that didactic transposition will occur (Modelski et al., 2019; Ribeiro Junior et al., 2020). Despite these difficulties, the pandemic caused by SARS-CoV-2 broke the traditional in-person teaching model, and indicated the importance for the school community to be prepared with extended and updated educational relationships through the use of ICTs (Beneditto, 2020).

In relation to the sciences, various subjects can be wrongly promoted through social networks, which generates echo chambers and negatively impacts on the behavior of young people, as well as the credibility of science (Gravina and Munk, 2019). As such, it is necessary to empower students and enable them to acquire the necessary skills to access, understand, analyze, evaluate, and produce content; in addition to knowing how to distinguish between real and fake news (FernándezGarcia, 2018).

In schools in the Tocantina region of the state of Maranhão (northeastern Brazil), it was observed that social media has the power to influence not only the perception, but also the behavior of students. When they first obtain information through social networks, they are more likely to believe in fake news and/or conspiracy theories related to COVID-19 and, consequently, ignore the measures being enforced to contain the disease at one of the most worrying moments of the pandemic, such as in April 2020, when the peak of the first wave of the pandemic in Brazil struck. On the other hand, informing themselves from scientific sources and/or reliable sources, such as newspaper websites, made students better understand the epidemiological phenomenon that afflicted them, which led them to be more prudent regarding the containment measures of the new coronavirus (Lima \& Silva, 2020).

In view of the negative socio-educational consequences that the spread of fake news can bring, it is important to contextualize this subject in the school environment, because, in today's schools, the teacher not only can, but also should, act in combating the spread of fake news and help break this vicious and harmful cycle. Given this scenario, the present study aimed to apply and evaluate the didactic approach to combat fake news proposed by Gravina and Munk (2019), which was adapted to ERE focusing on COID-19, via scientific literacy.

\section{Methodology}

\subsection{Sampling and design}

This work was developed in two state public schools located in the city of Imperatriz, west Maranhão, in northeastern

Brazil, which we will refer to here as CEEG and CEDPS. The choice of these two schools was based on the finding that fake 
news, disseminated through social networks, would likely be influencing students to ignore containment measures against COVID-19 (Lima \& Silva 2020). This is a quali-quanti study, since the analysis of quantitative and qualitative aspects complemented each other and allowed for a better understanding of the results (Pereira et al., 2018).

The target audience consists of 35 high school students, from six classes, two of each of the $10^{\text {th }}, 11^{\text {th }}$ and $12^{\text {th }}$ grades. The students were informed of the activity and that it would be considered as one of the components of the bimonthly tests, and assigned in the Biology class. An alternative evaluation activity was made available to those who could not participate for any reason. All ethical guidelines of CNS Resolution 510/2016 were followed.

The pedagogical proposal was developed between the months of October and December 2020 for nine weeks. The workshops took place remotely to obtain data, follow-up and provide guidance via video conferences (Google Meet), and all the safety standards required by the World Health Organization (WHO) during the COVID-19 pandemic were followed.

The workshops took place weekly with two classes (50 minutes each) for the $10^{\text {th }}$ and $11^{\text {th }}$ grade classes and three classes for the classes of $12^{\text {th }}$, according to the weekly workload of each class for the biology classes. Thus, in total, 18 classes were given to the $10^{\text {th }}$ and $11^{\text {th }}$ grade classes; and 27 classes to the $12^{\text {th }}$ grade class. In the meantime, it was possible to integrate subjects foreseen in the teaching plan of the class in each class, such as induced immunization, viruses and organic evolution, with this pedagogical proposal, thus promoting the contextualization of the contents in the daily life of the student.

The methodology of Gravina and Munk (2019) was adapted to ERE in order to problematize the theme. To this end, the workshops were held in two stages: one to draw attention and sensitize students to the topic and another to identify the characteristics of fake news, contrasting them with news from reliable sources.

\subsection{Step 1: Awareness}

This step consisted of the first approach to the theme in which students were presented with comic strips (Paz, 2020; Suporte, 2020) that criticize misinformation that is propagated on social networks (Figure 1) through slide sharing during the video lesson. In addition, the 2011 film "Contagion" was highlighted and made available through the Google Classroom platform, in order to illustrate the harmful potential of fake news; and the 2020 documentary "The Social Dilemma", which focuses on the manipulation of social behavior through the use of social media. Both films were purchased and then screened during the class. With these tools, it was possible to awaken the attention and awareness of the subject for the following steps. At this stage, the 35 students $\left(10^{\text {th }}\right.$ grade $=8 ; 11^{\text {th }}$ grade $=5$ and $12^{\text {th }}$ grade $\left.=22\right)$ expressed interest in continuing to participate in the study. 
Figure 1 - Examples of comic strips that criticize fake news and which were presented to students as a way of raising awareness on the topic.
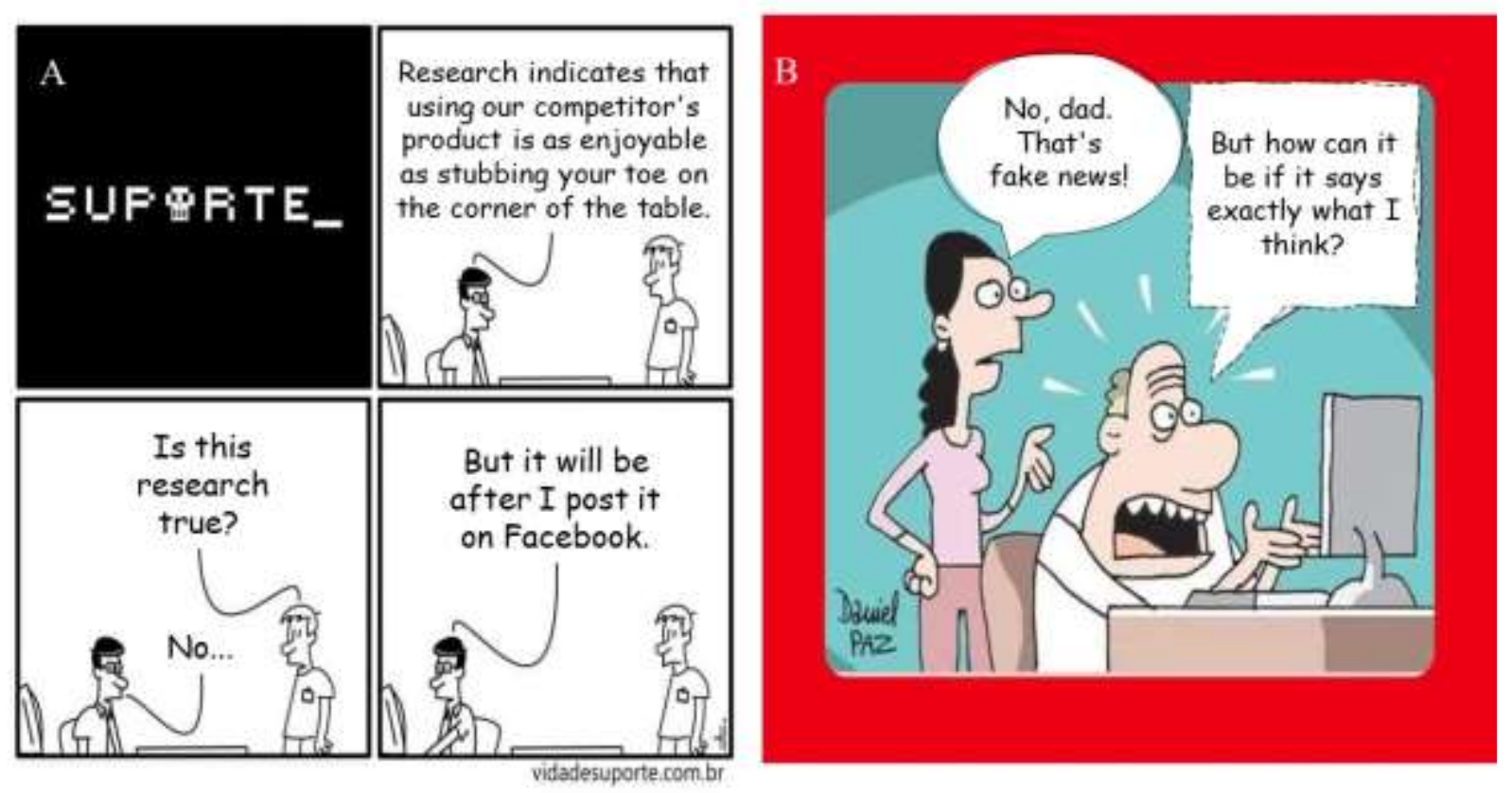

Source: A: adapted from Suporte (2020) and B: adapted from Paz (2020).

\subsection{Step 2: Differentiation between the characteristics of fake news and news from reliable sources}

In the second step, the students surveyed in the previous step were randomly distributed into 23 groups of no more than five members each, for which one of the three dichotomous sets of texts defined as A (10 groups), B (4 groups) or C (9 groups) (Table 1) were drawn. In each text, there is one that is recognizably flawed, and the other is from a trusted source, both are related to the biological aspects of COVID-19, and the students were challenged to identify the characteristics that indicate whether it is fake news or news that can be trusted and/or is true; and, therefore, carry out a comparison of these two streams of information in order to improve their ability to distinguish between the two types of information and also measure this ability.

Table 1 - Texts used in the comparison between news from reliable sources per dichotomous set in contrast to fake news and tasks that students were instructed to perform using this comparison.

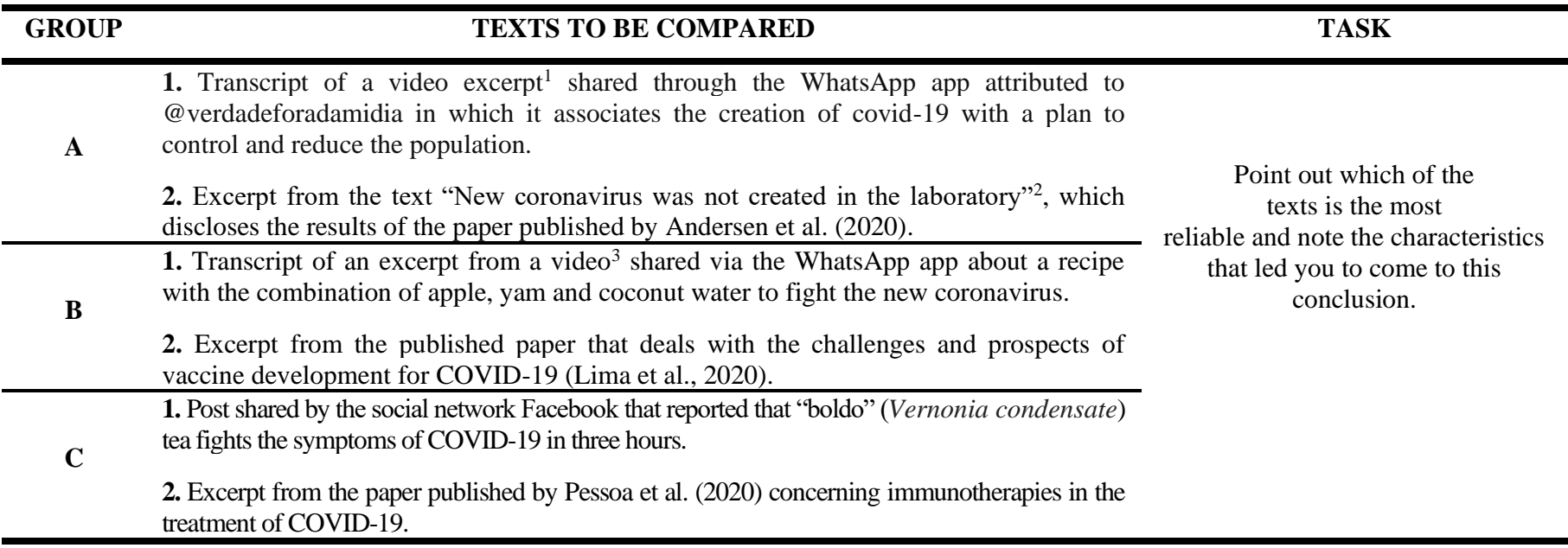

1 - Access Link: https://drive.google.com/file/d/14etTmzlBh0Nq7x29_7WAF10NLUgorD8Z/view?usp=sharing; 2 - Access Link: https ://coronavirus.bahia.fiocruz.br/novo-coronavirus-nao-foi-criado-em-laboratorio/; 3 - Access Link: https://drive .google.com/file/d /1fQN81G 
BhJ12MRf3wwhPiKr5k2A1eRcuo/view?usp=sharing; 4 - Access Link: https://drive.google.com/file/d/1sbYvUNWSyLia17EpV 9fAvtc3EcqfzvhI/view?usp=sharing. Source: authors.

A comparative table was made available (Table 2) to record the answers by the students during the execution of the task and it was recommended that the answers be edited within the digital document itself and sent through the Google Classroom platform. In the answers, they pointed out which of the texts was the most and least reliable and indicated what characteristics of each text made them come to this conclusion.

On this platform, the students were provided with options of features that could help identify possible fake news that were extracted from Gravina and Munk (2019), such as evaluate the source, the site, the author of the content and the structure of the text (spelling errors); see if it has clarity; language designed to appeal; little information; inaccurate statements (those without basis); inaccuracy in the data (I think, therefore I share); history of the author (have you ever been involved in rumors?); the communication vehicle (Is its credibility known?); did not name the cited scientists "the news is full of opinions; pay attention to the date of its publication; absence of bibliographic references; read beyond the title and subtitle; search on other content sites; share only after checking if the information is correct.

Table 2. Comparative table made available to students to assist them in the execution of the task of comparison between fake news texts and reliable and/or truthful texts.

\begin{tabular}{|c|c|c|}
\hline \multicolumn{1}{|c|}{ Question } & \multicolumn{2}{|c|}{ Comparative table } \\
\cline { 2 - 3 } & Text 1 & Text 2 \\
\hline Which text is the most reliable? Which text is the least reliable? & & \\
\hline What features found in the text justify your answer? & & \\
\hline
\end{tabular}

Source: Authors.

\subsection{Data analysis}

From the answers, descriptive and exploratory analyses were carried out from the compilation of the database in tables that include the characteristics perceived in fake news and those found in the news from reliable sources.

\section{Case report}

\subsection{General analysis}

It was observed that $95.7 \%$ of the questionnaires indicated that the Text 2 of each of the textual groups was the most reliable. A total of 18 textual characteristics were detected by the students, both indicative of fake news and trying to make the text seem reliable. Regarding the textual characteristics that are indicative of fake news, 50\% are new in the present study while $50 \%$ of these had been previously reported by Gravina and Munk (2019) (Table 3). Regarding the characteristics that confer trustworthiness to the information, 83.33\% are new when compared with those reported by Gravina and Munk (2019) (Table 4). These data indicate that the adaptation of this pedagogical work to the ERE was not only effective, but also revealed a relevant percentage of new characteristics. 


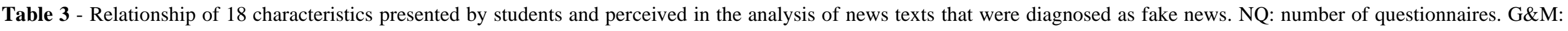
features reported by Gravina and Munk (2019). PS: characteristics that are new in the present study.

\begin{tabular}{|c|c|c|c|c|c|c|c|}
\hline $\mathbf{N}^{\circ}$ & Characteristics perceived by the students in fake news & NQ & Grade & Group & $\%$ & G\&M & PS \\
\hline 1 & Inaccurate, unfounded, absurd or out of context information & 9 & $10^{\text {th }}, 11^{\text {th }}$ and & $\begin{array}{l}\mathrm{A}, \mathrm{B} \text { and } \\
\mathrm{C}\end{array}$ & 50.0 & $\mathrm{X}$ & \\
\hline 2 & Source without any credibility, such as videos and posts of strangers, posted on Facebook and/or WhatsApp & 6 & $10^{\text {th }}$ and $12^{\text {th }}$ & $\mathrm{B}$ and $\mathrm{C}$ & 33.3 & $\mathrm{X}$ & \\
\hline 3 & Presentation of arguments without any scientific evidence & 6 & $12^{\text {th }}$ & B & 33.3 & & $\mathrm{X}$ \\
\hline 4 & Cites a cure with little or no acceptance & 6 & $\begin{array}{l}10^{\text {th }}, 11^{\text {th }} \text { and } \\
12^{\text {th }}\end{array}$ & $\mathrm{C}$ and $\mathrm{B}$ & 33.3 & & $\mathrm{X}$ \\
\hline 5 & Post does not cite the source of the information or website on which the content can be found & 6 & $\begin{array}{l}10^{\text {th }}, 11^{\text {th }} \text { and } \\
12^{\text {th }}\end{array}$ & $\mathrm{A}$ and $\mathrm{C}$ & 33.3 & & $\mathrm{X}$ \\
\hline 6 & $\begin{array}{l}\text { Absence of academic training of those who disclose the information or does not present the opinion of experts in the } \\
\text { field }\end{array}$ & 5 & $10^{\text {th }}$ & $\mathrm{A}$ and $\mathrm{B}$ & 27.7 & & $\mathrm{X}$ \\
\hline 7 & Absence of bibliographic references & 4 & $10^{\text {th }}$ and $11^{\text {th }}$ & $\begin{array}{l}\text { A, B and } \\
\text { C }\end{array}$ & 22.2 & $\mathrm{X}$ & \\
\hline 8 & Language designed to appeal or use of imperative mode & 4 & $10^{\text {th }}$ & $\mathrm{A}$ and $\mathrm{B}$ & 22.2 & $\mathrm{X}$ & \\
\hline 9 & Absence of a link that can give more information about the publication & 3 & $10^{\text {th }}$ & A & 16.6 & & $\mathrm{X}$ \\
\hline 10 & Inappropriate terms and one that generally not found on websites or in journalistic texts & 3 & $12^{\text {th }}$ & A & 16.6 & & $\mathrm{X}$ \\
\hline 11 & Inaccuracy in the data cited & 3 & $10^{\text {th }}$ and $12^{\text {th }}$ & $\begin{array}{l}\mathrm{A}, \mathrm{B} \text { and } \\
\mathrm{C}\end{array}$ & 16.6 & $\mathrm{X}$ & \\
\hline 12 & Spelling, punctuation and verb-noun concordance errors & 3 & $12^{\text {th }}$ & $\mathrm{C}$ & 16.6 & $\mathrm{X}$ & \\
\hline 13 & Absence of content author name & 3 & $10^{\text {th }}$ and $12^{\text {th }}$ & $\mathrm{A}$ and $\mathrm{B}$ & 16.6 & & $\mathrm{X}$ \\
\hline 14 & Absence of clarity in the language of the text & 2 & $10^{\text {th }}$ and $12^{\text {th }}$ & $\mathrm{A}$ and $\mathrm{B}$ & 11.1 & $\mathrm{X}$ & \\
\hline 15 & Presents little information on the subject & 1 & $12^{\text {th }}$ & $\mathrm{C}$ & 5.5 & $\mathrm{X}$ & \\
\hline 16 & No publication date & 1 & $12^{\text {th }}$ & $\mathrm{C}$ & 5.5 & & $\mathrm{X}$ \\
\hline 17 & Does not explain why the author is the only one who knows about the subject & 1 & $10^{\text {th }}$ & A & 5.5 & & $\mathrm{X}$ \\
\hline 18 & Attributes the information to scientists, but does not name them & 1 & $12^{\text {th }}$ & $\mathrm{C}$ & 5.5 & $\mathrm{X}$ & \\
\hline 18 & Total & 67 & & & & 9 & 9 \\
\hline
\end{tabular}

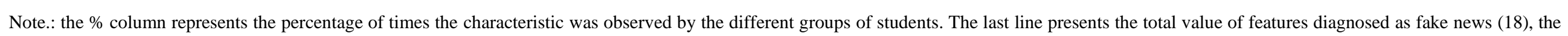
number of redundant fake news features observed by the students (67), the amount of correspondence with the study of Gravina and Munk (2019) (9) and the new ones in the present study (9). Source: Authors. 


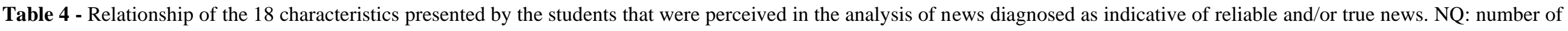
questionnaires. G\&M: Gravina and Munk (2019). PS: present study.

\begin{tabular}{|c|c|c|c|c|c|c|c|}
\hline $\mathbf{N}^{\mathbf{0}}$ & Characteristics perceived by students as indicative of reliable and/or true news & NQ & Grade & Group & $\%$ & G\&M & PS \\
\hline 1 & Contains bibliographic references & 7 & $10^{\text {th }}, 11^{\text {th }}$ and $12^{\text {th }}$ & $A$ and $B$ & 38.88 & $\mathrm{X}$ & \\
\hline 2 & The source, website and information cited is reliable & 7 & $10^{\text {th }}$ and $12^{\text {th }}$ & $\mathrm{A}, \mathrm{B}$ and $\mathrm{C}$ & 38.88 & & $\mathrm{X}$ \\
\hline 3 & Academic text or information based on scientific papers & 5 & $10^{\text {th }}$ and $12^{\text {th }}$ & $\mathrm{A}, \mathrm{B}$ and $\mathrm{C}$ & 27.77 & & $\mathrm{X}$ \\
\hline 4 & Displays the publication date & 3 & $10^{\text {th }}$ and $12^{\text {th }}$ & $\mathrm{A}$ and $\mathrm{C}$ & 16.66 & & $\mathrm{X}$ \\
\hline 5 & Mentions the name of the author of the content & 3 & $11^{\text {th }}$ and $12^{\text {th }}$ & $A$ and $B$ & 16.66 & & $\mathrm{X}$ \\
\hline 6 & Presence of page links that provide more information & 3 & $10^{\text {th }}$ and $11^{\text {th }}$ & $A$ and $B$ & 16.66 & & $\mathrm{X}$ \\
\hline 7 & Reports that research is being carried out on the topic & 3 & $10^{\text {th }}$ and $12^{\text {th }}$ & $\mathrm{A}$ and $\mathrm{C}$ & 16.66 & & $\mathrm{X}$ \\
\hline 8 & Conveys credibility by commenting that the vaccine is the way to fight the disease & 3 & $10^{\text {th }}, 11^{\text {th }}$ and $12^{\text {th }}$ & $\mathrm{B}$ and $\mathrm{C}$ & 16.66 & & $\mathrm{X}$ \\
\hline 9 & Few or no spelling and punctuation errors & 2 & $11^{\text {th }}$ and $12^{\text {th }}$ & $\mathrm{B}$ and $\mathrm{C}$ & 11.11 & & $\mathrm{X}$ \\
\hline 10 & Describes details of the information & 2 & $10^{\text {th }}$ and $12^{\text {th }}$ & A & 11.11 & & $\mathrm{X}$ \\
\hline 11 & Contains arguments of experts & 2 & $10^{\text {th }}$ and $12^{\text {th }}$ & $A$ and $B$ & 11.11 & $\mathrm{X}$ & \\
\hline 12 & Well-structured text & 2 & $10^{\text {th }}$ and $12^{\text {th }}$ & $A$ and $B$ & 11.11 & & $\mathrm{X}$ \\
\hline 13 & The text is clear & 2 & $10^{\text {th }}$ and $12^{\text {th }}$ & $A$ and $B$ & 11.11 & & $\mathrm{X}$ \\
\hline 14 & Correctly written text & 2 & $11^{\text {th }}$ and $12^{\text {th }}$ & $\mathrm{C}$ & 11.11 & & $\mathrm{X}$ \\
\hline 15 & It is an excerpt from a paper published in a scientific journal & 2 & $10^{\text {th }}$ & A & 11.11 & & $\mathrm{X}$ \\
\hline 16 & Reports on the vaccine development process and its challenges & 2 & $11^{\text {th }}$ and $12^{\text {th }}$ & $\mathrm{B}$ and $\mathrm{C}$ & 11.11 & & $\mathrm{X}$ \\
\hline 17 & Possibility to find the topic in other news sites & 1 & $12^{\text {th }}$ & A & 5.55 & $\mathrm{X}$ & \\
\hline 18 & Accuracy in the data cited & 1 & $12^{\text {th }}$ & $\mathrm{B}$ & 5.55 & & $\mathrm{X}$ \\
\hline 18 & Total & 52 & & & & 3 & 15 \\
\hline
\end{tabular}

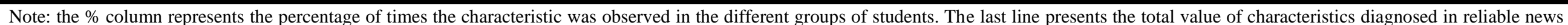

(18), redundant characteristics attributed to reliable news (52), the amount of correspondence with the study of Gravina and Munk (2019) (3) and new ones in the present work (15).

Source: Authors. 
In all, six characteristics of fake news highlighted in the study by Gravina and Munk (2019) were not reported by the students in the present study (Table 3). These were language designed to appeal on an emotional level; very flashy titles; excessive use of the imperative mode; old dates; discredits professional categories; and author's history (have you ever been involved in rumors?).

One reliable news feature that is reported by Gravina and Munk (2019) found no exact match in the present study, i.e., "use of elements of scientific method in the description of the news". This characteristic, however, is broad and subjective so that characteristics 10,12,13, 14 and 18 of Table 4 fit this definition.

When comparing the data from the different high school grades, it was observed that the highest percentage (42.2\%) of news characteristics diagnosed as fake news was reported by $12^{\text {th }}$ graders, while the students of the $10^{\text {th }}$ grade pointed out the highest proportion (40.4\%) of news features that could be help to diagnose new as reliable and/or truthful (Figure 2A).

On the other hand, it was also observed that the dichotomous set (Table 1) that refers to Group $\mathrm{C}$ generated the highest proportion of characteristics, not only for the identification of fake news $(40.6 \%)$ but also for true and/or reliable news $(44.2 \%)$ (Figure $2 \mathrm{~B})$.

Figure 2 - Proportion of the number of characteristics indicated in the recognition of fake and true news by students, by high school grade (A) and by groups of texts (B).

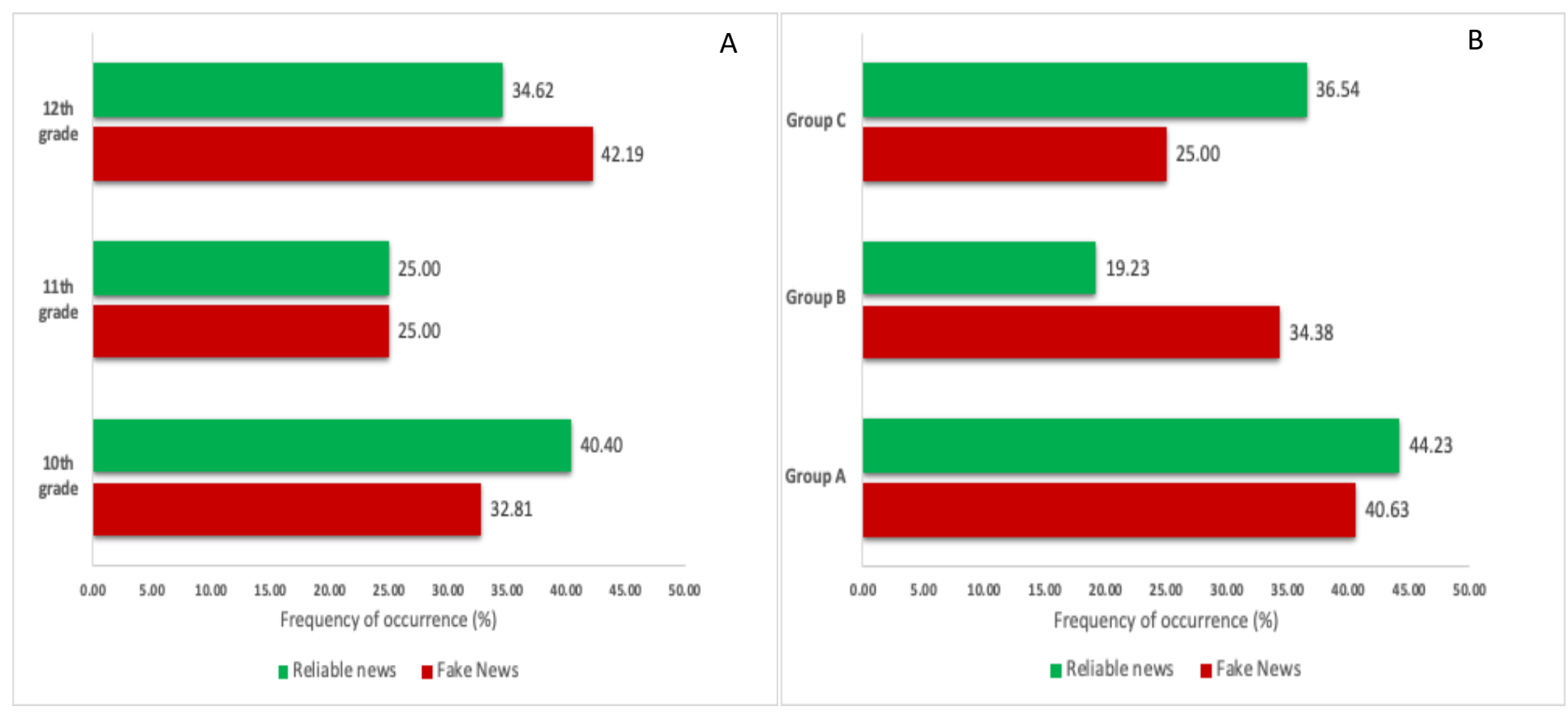

Source: Authors.

Although the recommendation was for the answers to be sent by the Google Classroom platform in document format (doc or docx) (Figure 3C), it was observed that $82.6 \%$ of the groups forwarded the questionnaires in other formats and/or another platform (pdf or jpg forwarded by Google Classroom or WhatsApp). It should be noted that $30.4 \%$ of the groups recorded their responses via photographs of notes on sheets of paper and sent them in JPEG format, via WhatsApp (Figure 3). This data may reflect the difficulty of students in using digital platforms aimed at teaching. 
Figure 3 - Examples of the three formats submitted by students. JPEG format showing notes sent by WhatsApp (A), in doc or docx format (B) and in PDF (C), both sent via the Google Classroom platform.

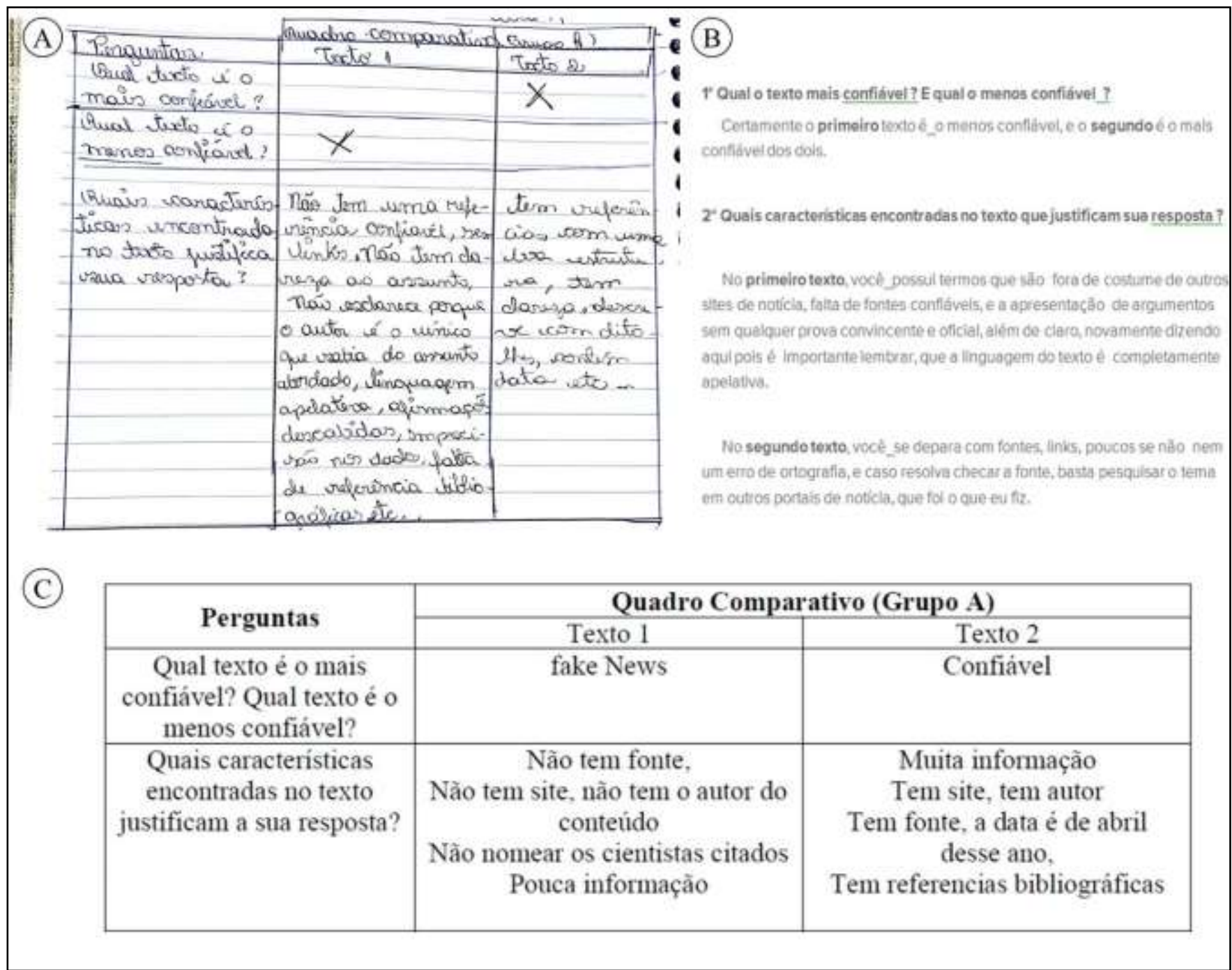

Source: Authors.

\subsection{Characteristics found in fake news}

In the fake news analyzed by the students, the number of characteristics found by them totaled 18. Within this category, the characteristic most often mentioned (50\%) by the groups was "information that is inaccurate, unfounded, absurd or out of context". This was followed by "source without credibility, such as videos and posts of strangers broadcast on Facebook and/or WhatsApp", "presentation of arguments without any scientific evidence", "cites cure with little or no acceptance" and "does not cite the source of information or site where the content can be found", all with $33.33 \%$ of the mentions (Table 3).

Although the aim of the present proposal was to target mainly the critical sense of the students when analyzing the texts, they also detected specific fake news information related to COVID-19 that reports on the supposed cure of the disease as follows: "indicates the cure of COVID-19 in a simple and fast way"; "teaches novel home remedy for the cure of COVID19" and "that boldo tea is able to cure COVID-19". Misleading news about the organic evolution of the virus was also detected: "that the virus was created in the laboratory in order to control the growth of the human population" (Figure 4A). 


\subsection{Characteristics found in reliable and/or true news}

The students indicated 18 textual characteristics that give credibility to information. In this respect, the characteristic most frequently mentioned $(38.88 \%)$ by the groups was "contains bibliographic references" and "the source, website and information cited are reliable". Next, there is "academic text or information based on scientific papers" with $27.77 \%$ of mentions. This was followed by "presents the dates of the publications", "mentions the name of the author of the content", "presence of links to pages that provide more information", "reports that research is being carried out on the topic" and "conveys credibility by commenting that the vaccine is the way to fight the disease", all with $16.66 \%$ of mentions (Table 4).

In addition to the textual characteristics, one specific trait of reliable news topics is the theme about the importance of tests and how they are carried out and how they prove the effectiveness of vaccines was highlighted. The students mentioned that: "before scientists test vaccines on humans, they test them first on animals" and "the text is reliable because it addresses the topic immunotherapy for treatment" (Figure 4B).

On organic evolution, it was mentioned that "the virus was not created in the laboratory due to its evolution and its form of reaction in the human body". The students also indicated that reliable news highlights the importance of social distancing: "it alerts the population to stay at home" (Figure 4B).

Figure 4 - Illustrative representation of the main characteristics of fake news and reliable news found by students related to COVID-19.

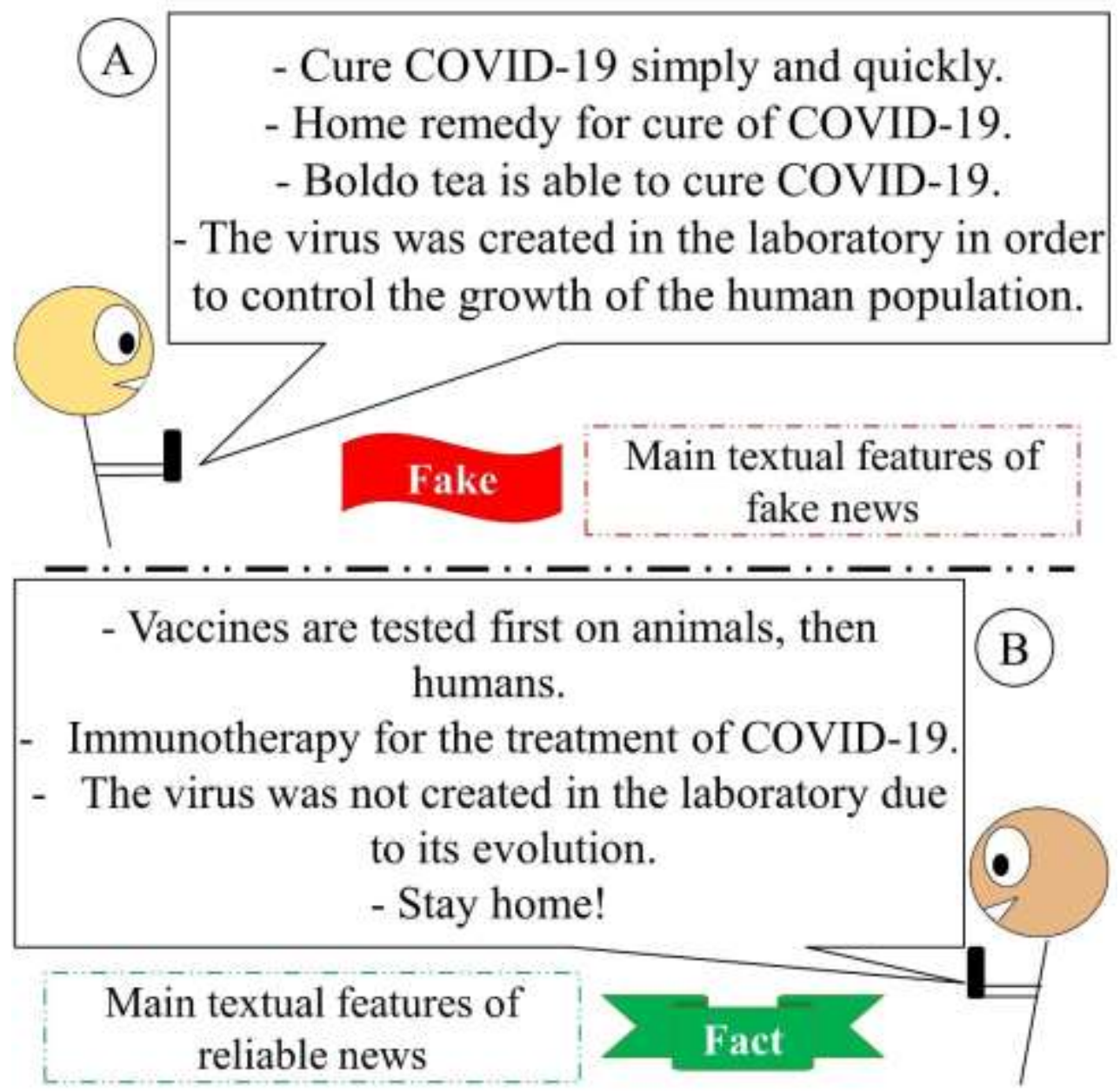

Source: Authors. 


\section{Discussion}

This paper presents a successful adaptation of scientific literacy via ERE that is aimed at combating fake news related to COVID-19, and is based on Gravina and Munk (2019). In the process of investigation of fake news and reliable news, the students made textual records, which were aided by the comparative table (Table 2). This was done because the production of records that involve writing is a fundamental aspect of the construction of scientific concepts in the teaching of science (Carvalho, 2013).

Although the total number of students enrolled in the classes used in the application of this pedagogical action totaled 225, only 35 participated. This may symbolize the increase in school evasion in the year 2020 as a result of the pandemic. According to the state government, in Maranhão, $21 \%$ of students did not attend ERE classes. This number reached more than $50 \%$ in the state of São Paulo (Jornal Nacional, 2020).

A considerable percentage of the groups (30.4\%) sent their answers in the form of photos of what was written in their notebooks via WhatsApp. The students attributed this to difficulties in editing the file in document format in the Word program using the mobile phone, which may be a consequence of the lack of a computer at home. This corroborates the fact that of the $71 \%$ of Brazilians who have access to the internet, $99 \%$ make use of the mobile phone and this points to a "no" to the question posed by Marcon (2020): “Are teaching-learning processes being thought in a context in which the student only has access to the internet via mobile phone?".

The difficulty of handling ICTs by students in this study is inserted in a context of digital exclusion faced by Brazilians, especially in the lower social strata (classes DE), the main clientele of public schools in relation to basic education. The first aspect of digital exclusion concerns the lack of technological artifacts and access to the Internet. In 2019 , only $14 \%$ of Brazilian households belonging to classes D and E had computers, a percentage below the national average of $39 \%$. The same happens with Internet access, because $71 \%$ of Brazilians access the internet, but this percentage drops to $50 \%$ in classes D and E (NIC.br, 2020). This reveals a deep social discrepancy so that, in a scenario of social isolation, the conditions of access to computers in homes are different depending on purchasing power; and the financial vulnerability of the population interferes and limits access to the Internet (Marcon, 2020; De Oliveira et al., 2020).

Another face of digital exclusion refers to technological dominance and fluency. In this axis, the central role of digital literacy is observed by recognizing the urgency of ensuring equity of access, as well as allowing the promotion of autonomy of subjects through digital network technologies, admitting their communicative, educational and political potential (Marcon, 2015). The schools analyzed in the present study are the same schools in which students who are informed about the pandemic primarily through social networks tended to believe that SARS-CoV-2 was created in the laboratory, and were inclined to practice fewer measures to contain the spread of the virus and to defend the indiscriminate use of hydroxychloroquine by all infected individuals (Lima and Silva 2020).

This study presents a scientific literacy approach that can raise the students' critical sense and help break the vicious cycle of fake news. Working to combat the high-scale deception propagated by social networks is of fundamental importance in the contemporary world, given that fake news interferes in the real world and can have serious consequences for decisionmaking on a range of relevant social issues, ranging from climate change and vaccinations to international relations (Poland and Spier, 2010; Linden et al., 2017; Van der Linden et al., 2017; Lazer et al., 2018).

A low level of health literacy makes people who suspect symptoms related to COVID-19 feel more stressed out and depressed than people with higher levels of health literacy (Nguyen et al., 2020), which also happens to medical students in regards to their fear of the disease (Nguyen et al., 2020). Thus, educating the population is an effective way to reduce fear and stress related to the pandemic (Moscadelli et al., 2020). Although this work is not specific to health literacy, it collaborates in this aspect by promoting experience in scientific literacy, which is an understanding that serves as the basis for health literacy. 
Nine textual characteristics of fake news and 15 characteristics of reliable news are new in the present study, which represents the same amount of new characteristics of fake news and three times more the amount of new characteristics for reliable news (5) in relation to the work of Gravina and Munk (2019). Taking into account the pioneering nature of this study, the relevant proportion of characteristics (fake news and reliable news) may reflect the previous usefulness of two approaches not used by Gravina and Munk (2019): by indicating points in the text that the students would need to pay more attention to the diagnosis of fake news (Step 1;2.2), together with the use of the comparative table (Table 2).

It is noted that most of the characteristics pointed out are opposites between fake and reliable news. Learning to consciously make this contrast is important so that the student is able to identify other fake news to which they will eventually be exposed. Knowing how to correctly discern between what is true and what is false in social networks characterizes a problem situation that can be improved in the school environment and within the scope of scientific literacy, by allowing students to gain knowledge and skills that allow them greater affinity with the technological innovations present in their daily lives (Scarpa and Silva, 2013).

One characteristic of fake news, which occupies the second place among those most frequently mentioned by the students in the present study (33.33\%) "Source credibility, and how-to videos and posts from people you know broadcasted in the social networking environment, Facebook and/or WhatsApp", is in agreement with the findings of a study carried out in Brazil, has revealed WhatsApp as the main vehicle for the sharing of fake news, which is followed by Instagram and Facebook (Galhardi et al., 2020).

In 2020, it was observed that $99 \%$ of mobile phones in Brazil had WhatsApp installed, this being the highest percentage ever recorded by the app in five years of research (Oliveira, 2020). With this, it is a leader in the spread of false rumors. The trend today in Brazil is to buy a number to use WhatsApp, rather than a number for phone calls. This was motivated by a history that involves the practice of high SMS sending rates, followed by a phase in which users could use more than one SIM card on the same mobile device, and this permitted the option of contacting different telephone numbers associated with different carriers. This practice has been decreasing with the use of WhatsApp since it resulted in the termination of the difference in prices of service fees practiced by these operators. Its use and functionalities have increased over time, such as audio message (favoring the less literate without exposing this condition), creation and participation in different groups, sending of videos and photos, video and audio calls, fostering of business, payments (Saboia, 2016).

The increasing use of WhatsApp's functions is also a reflection of the fact that there is currently the option to purchase unlimited internet service packages from mobile operators for some social networks, including the said application. With a limited data package, there will be little search for news on trusted sites. This corroborates the idea that citizens in Brazil are informed by social networks giving them fertile fields for the dissemination of fake news, and this is potentiated by the harmful bias that the number of times a news item is shared the greater its credibility. This situation is a counterpoint to the fact that traditional media, such as newspapers, and written, spoken or televised reports, are more reliable.

Scientific communication is also important for combating the spread fake news related to COVID-19, since there are already reports that students who inform themselves based on scientific media, such as the websites of scientific journals or read scientific papers, have tended to be more prudent in the containment measures against the pandemic (Lima and Silva 2020). In this context, studies such as the present study that deals with scientific literacy, are fundamental, especially at such an adverse moment in the midst of a viral pandemic and its different impacts.

Fake news related to COVID-19 that address the cure of the disease in the following way: "indicates the cure of COVID-19 in a simple and fast way"; "teaches new home remedy for cure of COVID-19" and "that boldo tea is able to cure COVID-19" (Figure 4A) find echoes in the literature in works that have verified that prophylaxis and simple, fast and homemade cure recipes are typical of fake news related to COVID-19 (Galhardi et al., 2020; Moscadelli et al., 2020). 
The propagated untruth about the organic evolution of the virus that "the virus had been created in the laboratory" was also observed in the study by Moscadelli et al. (2020) and had higher rates of links and shares (65.6\%) in relation to links and sharing of reliable news (34.4\%) on the topic "laboratory". This false news was propagated by the government of the United States of America (USA) by saying that SARS-CoV-2 was produced by a Chinese laboratory in Wuhan (UOL, 2021), and is part of a series of attacks that contributed to further complicate political relations between the US and China, the two largest economies in the world, to the point of some calling it a new cold war (BBC, 2021). In this way, fake news has become a political tool used to discredit any one of the countries, inflaming already difficult diplomatic relations (CNN, 2021). This shows the global dimension that the spread of seemingly "harmless" fake news can reach.

\section{Conclusion}

The adapting of the pedagogical proposal of scientific literacy through textual analysis to use in ERE that was performed in the present study was effective, and resulted in several new characteristics of fake news and reliable news, in addition to finding results that corresponded to those of Gravina and Munk (2019).

The textual characteristics of fake news and reliable news, as well as the specific fake news about COVID-19 found in the present study can be used to support work that aims to prepare students to better understand what is true and what is a lie in the world of the Internet, especially on social media. We argue that literacy, research and scientific dissemination are paramount in the fight against fake news and these need to be stimulated since basic education for this very purpose.

Although it was not the objective of this study, it was possible to indicate the effects of social inequalities linked to digital exclusion, which generates difficulties both of access to computers and the Internet, as well as digital fluency. Given this, there is interesting research to be done aimed at assessing the levels of digital exclusion in the schools studied, as well as encouraging public policies aimed at reducing social inequalities and increasing digital inclusion, not only at the local level, but also at the national level. It is also recommended that future studies propose pedagogical actions that aim to stimulate the reporting and/or exclusion of misleading news detected by students, in view of the harmful potential that fake news possesses.

Therefore, it is suggested that future studies focus on answering the following questions: (1) Do the students in public schools, especially in the schools analyzed in this work, suffer from digital exclusion? To what level does this exclusion occur? (2) Should there be a pedagogical mechanism for reporting and/or excluding misleading news? And, in a broader sense, (3) what is the role of the school in combating fake news?

\section{Acknowledgments}

I am grateful to SEUC-MA, government of the state of Maranhão for the leave to pursue my doctorate degree; to the principals of the two schools Jeassimonne Paulino (CEDPS) and Adilson Santana (CEEG), and SEDECTI-FAPEAM, government of the state of Amazonas for the doctoral grant (POSGRAD/FAPEAM).

\section{References}

Andersen, K. G., Rambaut, A., Lipkin, W. I., Holmes, E. C., \& Garry, R. F. (2020). The proximal origin of SARS-CoV-2. Nature Medicine, 26 (4), 450-452. https://doi.org/10.1038/s41591-020-0820-9

BBC (2021). 'Guerra fria' entre Estados Unidos e China é 'ameaça global maior que coronavírus', diz Jeffrey Sachs. BBC News. https://www.bbc.com/portuguese/internacional-53127244. Acessado em junho de 2021.

Beneditto, A. P. M. Di. (2020). A educação básica durante o distanciamento social: O legado de 2020. Brazilian Journal of Development, 6(10), 82270-82282. https://doi.org/10.34117/bjdv6n10-599

Burkhardt, J. M. (2017). History of Fake News. Library Technology Reports, 53(8), 1-33. https://doi.org/10.5860/1tr.53n8

Carvalho, A. M. P. (2013). Ensino de Ciências por investigação: condições para implementação em sala de aula. Cengage Learning. 
Chassot, A. (2003). Alfabetização científica: uma possibilidade para a inclusão social. Revista Brasileira de Educação, 22, $157-158$.

CNN (2021). Trump gera mal-estar ao usar termo "vírus chinês” para se referir ao coronavírus, São Paulo (acessado em janeiro de 2021. CNN Brasil. https://www.cnnbrasil.com.br/internacional/2020/03/17/trump-gera-mal-estar-ao-usar-termo-virus-chines-para-se-referir-ao-coronavirus. Acessado em março de 2021.

Fernández-Garcia, N. (2018). Fake news: uma oportunidade para a alfabetização midiática. Nueva Sociedad, Julho, 112-123. http://nuso.org/articulo/fakenews-uma-oportunidade-para-alfabetizacao-midiatica/

Galhardi, C. P., Freire, N. P., Minayo, M. C. de S., \& Fagundes, M. C. M. (2020). Fato ou Fake? Uma análise da desinformação frente à pandemia da Covid19 no Brasil. Ciência \& Saúde Coletiva, 25(suppl 2), 4201-4210. https://doi.org/10.1590/1413-812320202510.2.28922020

Gravina, M. das G. P., \& Munk, M. (2019). Dinâmicas de oficinas de textos em biologia: ferramentas para a alfabetização científica em tempos de fake news. Experiências Em Ensino de Ciências, 14(3), 612-620.

Harari, Y. N. (2018). 21 lições para o século 21. In Companhia das Letras $\left(1^{\mathrm{a}}\right)$.

Jang, S. M., \& Kim, J. K. (2018). Third person effects of fake news: Fake news regulation and media literacy interventions. Computers in Human Behavior, 80, 295-302. https://doi.org/10.1016/j.chb.2017.11.034

Jang, S. M., Mckeever, B. W., Mckeever, R., \& Kim, J. K. (2017). From Social Media to Mainstream News: The Information Flow of the Vaccine-Autism Controversy in the US, Canada, and the UK. Health Communication, 34(1), 110-117. https://doi.org/10.1080/10410236.2017.1384433

Jornal Nacional, J. (2020). Percentual alto de alunos não tem acompanhado as aulas pela internet durante a pandemia. https://g1.globo.com/jornalnacional/noticia/2020/06/30/percentual-alto-de-alunos-nao-tem-acompanhado-as-aulas-pela-internet-durante-a-pandemia.ghtml. Acessado em janeiro de 2021.

Kahne, J., \& Bowyer, B. (2017). Educating for Democracy in a Partisan Age: Confronting the Challenges of Motivated Reasoning and Misinformation. American Educational Research Journal, 54(1), 3-34. https://doi.org/10.3102/0002831216679817

Lazer, D. M. J., Baum, M. A., Benkler, Y., Berinsky, A. J., Greenhill, K. M., Menczer, F., Metzger, M. J., Nyhan, B., Pennycook, G., Rothschild, D., Schudson, M., Sloman, S. A., Sunstein, C. R., Thorson, E. A., Watts, D. J., \& Zittrain, J. L. (2018). The science of fake news. Science, 359(6380), 1094-1096. https://doi.org/10.1126/science.aao2998

Lima, E., Almeida, A., \& Kfouri, R. (2020). Vacinas para COVID-19: perspectivas e desafios. Residência Pediátrica, 10(2), 9-11. https://doi.org/10.25060/residpediatr-2020.v10n2-04

Lima, R. C., \& Silva, V. R. da. (2020). Influência das Mídias Sociais na Percepção de Alunos do Ensino Médio da Região Tocantins do Maranhão sobre a Pandemia COVID-19. Experiências Em Ensino de Ciências, 15(3), 610-618. https://doi.org/10.36599/itapprv15n3-001

Linden, S. Van Der, Maibach, E., Cook, J., Leiserowitz, A., \& Lewandowsky, S. (2017). Inoculating against misinformation Both male and female advisers can " mother." Science, 358(6367), 4-6.

Ludovico, F. M., Molon, J., Barcellos, P. da S. C. C., \& Franco, S. R. K. (2020). Covid-19: desafios dos docentes na linha de frente da educação. Interfaces Científicas - Educação, 10(1), 58-74. https://doi.org/10.17564/2316-3828.2020v10n1p58-74

Mamede, M., \& Zimmermann, E. (2005). Letramento científico e CTS na formação de professores para o ensino de ciências. Enseñanza de Las Ciencias, Número Ext, 1-4.

Marcon, K. (2015). A inclusão digital na formação inicial de educadores a distância: estudo multicaso nas Universidades Abertas do Brasil e de Portugal. In LUME. Faculdade de Educação da Universidade Federal do Rio Grande do Sul (UFRGS).

Marcon, K. (2020). Inclusão E Exclusão Digital Em Contextos De Pandemia: Que Educação Estamos Praticando E Para Quem? Criar Educação, 9(2), 80. https://doi.org/10.18616/ce.v9i2.6047

Modelski, D., Giraffa, L. M. M., \& Casartelli, A. de O. (2019). Tecnologias digitais, formação docente e práticas pedagógicas. Educação e Pesquisa, 45, 1-17. https://doi.org/10.1590/s1678-4634201945180201

Moscadelli, A., Albora, G., Biamonte, M. A., Giorgetti, D., Innocenzio, M., Paoli, S., Lorini, C., Bonanni, P., \& Bonaccorsi, G. (2020). Fake news and covid19 in Italy: Results of a quantitative observational study. International Journal of Environmental Research and Public Health, 17(16), 1-13. https://doi.org/10.3390/ijerph17165850

Nguyen, H. C., Nguyen, M. H., Do, B. N., Tran, C. Q., Nguyen, T. T. P., Pham, K. M., Pham, L. V., Tran, K. V., Duong, T. T., Tran, T. V., Duong, T. H., Nguyen, T. T., Nguyen, Q. H., Hoang, T. M., Nguyen, K. T., Pham, T. T. M., Yang, S.-H., Chao, J. C.-J., \& Duong, T. Van. (2020). People with Suspected COVID-19 Symptoms Were More Likely Depressed and Had Lower Health-Related Quality of Life: The Potential Benefit of Health Literacy. Journal of Clinical Medicine, 9(4), 965. https://doi.org/10.3390/jcm9040965

Nguyen, H. T., Do, B. N., Pham, K. M., Kim, G. B., Dam, H. T. B., Nguyen, T. T., Nguyen, T. T. P., Nguyen, Y. H., Sørensen, K., Pleasant, A., \& Duong, T. Van. (2020). Fear of COVID-19 Scale-Associations of Its Scores with Health Literacy and Health-Related Behaviors among Medical Students. International Journal of Environmental Research and Public Health, 17(11), 4164. https://doi.org/10.3390/ijerph17114164

NIC.br (2020). Pesquisa sobre o uso das tecnologias de informação e comunicação: Pesquisa TIC Domicílios, ano 2019. http://cetic.br/arquivos/domicilios/2019/domicilios/\#tabelas

Oliveira, C. E. de, Dias, M. L., \& Almeida, R. S. de. (2020). Desafios Do Ensino Remoto Emergencial Nas Escolas Públicas Durante a Pandemia. Brazilian Journal of Development, 6(12), 102816-102821. https://doi.org/10.34117/bjdv6n12-684 
Research, Society and Development, v. 10, n. 13, e310101321442, 2021

(CC BY 4.0) | ISSN 2525-3409 | DOI: http://dx.doi.org/10.33448/rsd-v10i13.21442

Oliveira, M. (2020). WhatsApp está em 99\% dos smartphones no Brasil. Rota Da Inovação. http://rotadainovacao.com.br/whatsapp-presenca-recorde-em-99dos-smartphones-no-brasil/

Paz, D. (2020). Sindicontaspr. Sindicontaspr. https://sindicontaspr.org.br/?area=ver_clipping\&id=321 .

Pessoa, B. M. S., Barroso, C. T., Vila, D. J. C., Barbosa, E. M. L., Seffair, I. de A., Melo, J. V. O. de, Becil, J. N., Rodrigues, N. M. V., Freitas, P. H. A. G. de, Rocha, R. B., Bentes, T. M., Rodrigues, T. F., Dos-Santos, M. C., \& Boechat, A. L. (2020). Imunoterapias No Tratamento Da Covid-19. DESAFIOS - Revista Interdisciplinar Da Universidade Federal Do Tocantins, 7(Especial-3), 97-108. https://doi.org/10.20873/uftsuple2020-8848

Poland, G. A., \& Spier, R. (2010). Fear, misinformation, and innumerates: How the Wakefield paper, the press, and advocacy groups damaged the public health. Vaccine, 28(12), 2361-2362. https://doi.org/10.1016/j.vaccine.2010.02.052

Ribeiro Junior, M. C., Figueiredo, L. S., Oliveira, D. C. A. de, Parente, M. P. M., \& Holanda, J. dos S. (2020). Ensino Remoto em Tempos de Covid-19: Aplicações e Dificuldades de Acesso nos Estados do Piauí e Maranhão. Boletim de Conjuntura, 3(9), 107-126. https://doi.org/http://doi.org/10.5281/zenodo.4018034

Saboia, F. (2016). Messaging, The Rise of WhatsApp in Brazil Is About More than Just. Harvard Business Review Home. https://hbr.org/2016/04/the-rise-ofwhatsapp-in-brazil-is-about-more-than-just-messaging

Scarpa, D. L., \& Silva, M. B. (2013). A Biologia e o ensino de Ciências por investigação: dificuldades e possibilidades. In Anna Maria Pessoa de Carvalho (Ed.), Ensino de Ciências por investigação: condições para implementação em sala de aula (pp. 129-151). Cengage Learning.

Sousa Júnior, J. H. de, Raasch, M., Soares, J. C., \& Ribeiro, L. V. H. A. de S. (2020). Da Desinformação ao Caos: uma análise das Fake News frente à pandemia do Coronavírus (COVID-19) no Brasil. Cadernos de Prospecção, 13(2), 331-346.

Spence, P. R., Lachlan, K. A., Edwards, A., \& Edwards, C. (2016). Tweeting fast matters, but only if i think about it: Information updates on social media. Communication Quarterly, 64(1), 55-71. https://doi.org/10.1080/01463373.2015.1100644

Suporte (2020). Fake News. Vida de Suporte. https://vidadesuporte.com.br/suporte-a-serie/fake-news/.

UOL (2021). Trump diz que vírus foi criado em laboratório na China e a ameaça com tarifas. UOL. https://economia.uol.com.br/noticias/efe/2020/05/01/trump-diz-que-virus-foi-criado-em-laboratorio-na-china-e-a-ameaca-com-tarifas.htm. Acessado em março de 2021

Van der Linden, S., Leiserowitz, A., Rosenthal, S., \& Maibach, E. (2017). Inoculating the Public against Misinformation about Climate Change. Global Challenges, 1(2), 1600008. https://doi.org/10.1002/gch2.201600008 